\title{
乱流境界層風洞の数值シミュレーション NUMERICAL SIMULATION OF TURBULENT BOUNDARY LAYER WIND TUNNEL
}

\author{
丸山 敬* \\ Takashi MARUYAMA
}

\begin{abstract}
A boundary layer wind tunnel was simulated numerically. The three-dimensional simulation method of turbulent boundary layer over rough surfaces using a refined $k^{-} \varepsilon$ turbulence model was examined and it applicability was shown by comparing the numerical results with the experimental data. Using the simulating method described here, wind characteristics over rough surfaces and the effect of incident flows on a square cylinder were examined numerically. The good applicability of the simulation reults indicats that these preliminary calculations could be a powerful tool in the design of actual wind tunnel tests and the inlet conditions having various wind characteristics can be created by this method.
\end{abstract}

Keywords : wind tunnel test, three-dimensional numerical simulation, turbulent boundary layer, $k-\varepsilon$ turbulence model

風洞実験, 数值シミュレーション, 乱流境界層, $k-\varepsilon$ 乱流モデル

\section{1.はじめに}

’近年，コンピューターおよび計算技術の進歩に伴い， 建築の分野でも流体の数値計算を用いた研究が数多く見 られるようになってきた。これまで，単純な形状を持っ た物体については，かなり詳しい計算が可能になってき ているが，物体の形状あるいは接近流の気流性状自体が 複雑な場合には，平均的な物理量の予測が一部で実用段 階に達しているのを除けば，大部分はいまだ研究段階と 言って良いと思われる。現在, 構造物の耐風設計に必要 な風圧力や振動性状あるいは建築物周辺の風環境予測の ための風洞実験は，地表面付近の自然風を想定した乱流 境界層中で行われることが多い。この乱流境界層を数值 計算で発生させる場合, 流入気流性状, 圧力勾配, 境界 条件等が問題になる。特に, 地表面境界条件は計算結果 に大きな影響を及ぼし，その与え方によって地表面付近 の気流性状が左右される。風が問題となるような建物は, 市街地に建つ場合が多いが, 市街地では地表面に建物等, 多くの凹凸があり，これら粗度要素の影響をいかに計算 に取り込むかが重要な課題となる。筆者らは，この点に ついて一連の研究を行っており,これまで, 計算方法, 乱流モデル, 解析領域, メッシュ分割, 境界条件等につ いて検討してきた ${ }^{1 / 3)}$ 。また，千鳥状配列立方体粗度ブ
ロックを用いた粗面について，粗度形状と抵抗係数およ び長さスケールの関係を求め4),5), 粗度形状の違いや流 れ方向粗度変化に伴う気流性状の変化 ${ }^{6)} 2$ 次元計算に よって調べた。本報では,これらの成果を 3 次元計算に 拡張して風洞内に発達する乱流境界層の数值シミュレー ションに適用し，実験結果との比較によってその有効性 をを確かめる。また，直方体を用いた簡単な数値風洞実験 を行い，数値風洞への応用を考察した。

\section{2. 解析方法}

\section{1 概 要}

はじめに，風洞内の気流性状に応じた領域分割による 解析方法を検討する。乱流境界層を用いた風洞実験では, 図一1に示すように模型の風上側に置かれたラフネスに よって乱流境界層を発達させ，接近流の気流性状を粗度 形状によって制御する。風洞内は，流入口 $\mathrm{AD}$ から流 出口 $\mathrm{BC}$ に向かって, 以下のように気流性状の異なる 3 つの領域に大別できる。

領域 I : 粗度の風上側の領域で,形状は最も単純である。 床, 壁, 天井はいずれも滑面であり，この領域の解析手 法は基本的にチャンネル流れと同じである。計算を行う 際は，壁面境界条件の取り方が最も重要となるが, 他の

本報の一部は Eighth International Conference on Wind Engineering, 1991. 7, London, Canada において発表した。

* 京都大学防災研究所 助手. 修士 (工学) Research Assoc., Disaster Prevention Research Institute, Kyoto Univ., M. Eng. 


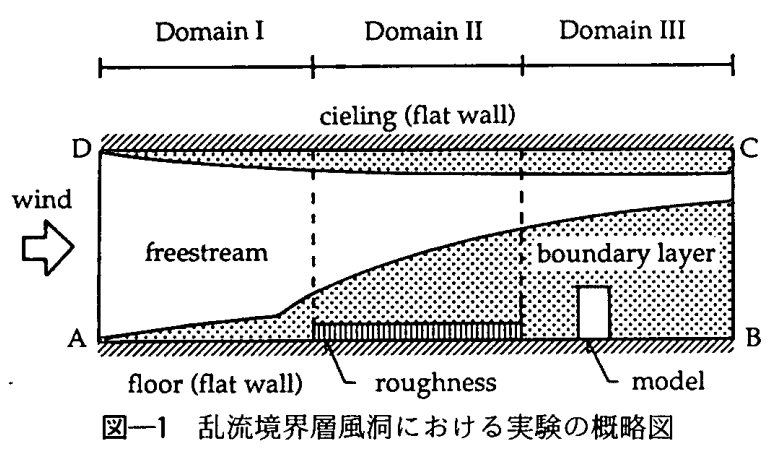

領域に比べると計算にとって流れの性質は良い。 領域 II : ラフネスがある領域で, 乱流境界層が発達し, 気流性状は粗度形状の影響を大きく受ける。したがって, この領域では粗度要素の影響をいかに計算に取り込むか に解析の成否がかかってくる。

領域 III ：実験対象之なる建物，橋，地形模型等が置かれ る領域で, 詳細な解析が要求される。解析精度は対象物 の形状，研究の目的等により変化し，さまざまな手法が 考えられる。例えば， $k-\varepsilon 2$ 方程式乱流モデル（以後， $k-\varepsilon$ モデルと呼ぶ）による直方体周りの 3 次元定常流れ 場の解析》 や，LES による立方体周りの非定常流れ場 の解析冬が挙げられる。また, 角柱周りの詳細な渦構造 を調べるために，非圧縮性ナビエ・ストークス方程式を 用いた直接計算"が挙げられる。この直接法によれば, 乱流のモデル化による誤差を回避できるが, 計算量はか なり多くなっしまう。

本報では，まず領域 I， 【の解析手法の開発に主眼を 置く。領域四に関しては簡単な適用例を示し，数値風洞 への応用を考察することにして，以下のような方針で解 析を行うことにした。

(1)：領域 I，IIでは，2 次流の計算等, 詳細な解析は行 わないとし，定常流れ場の計算を行う。

(2)：領域 II の粗度要素付近の 3 次元流れの詳細な解析は 行わないとし，時空間平均量を計算する。

(3)：領域 III では, 直方体周りの 3 次元定常流れ場の解析 を行う。

この結果, 乱流モデルには粗度形状および体積変化を

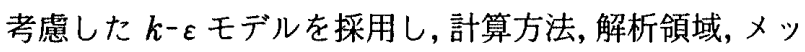
シュ分割, 境界条件等は, それぞれ, 領域に応じて適当 な手法を選択する。以下に詳細を述べる。

\section{2 乱流モデル}

用いた乱流モデルは，標準型 $k^{-} \varepsilon$ モデルに粗度要素 の影響を新たにモデル化して付け加え，粗度形状を抵抗 係数および長さスケールで計算に取り込み, 粗度要素の 体積変化も取り扱えるように改良を加えたもので゙)，3 次元について以下のように与えられる。 [連続の式]

$$
\frac{\partial G U_{i}}{\partial x_{i}}=0
$$

[平均流の輸送方程式]

$$
\begin{aligned}
G & \frac{\partial U_{i}}{\partial t}+\frac{\partial G U_{t} U_{j}}{\partial x_{j}} \\
& =-\frac{1}{\rho} \frac{\partial G P}{\partial x_{i}}-\frac{\partial G \overline{U_{i} U_{j}}}{\partial x_{j}}-G F_{x_{i}} .
\end{aligned}
$$

[ $K$ の輸送方程式 $]$

$$
\begin{aligned}
& G \frac{\partial K}{\partial t}+\frac{\partial G U_{j} K}{\partial x_{j}} \\
& \quad=\frac{\partial}{\partial x_{j}}\left(\frac{\nu_{t}}{\sigma_{k}} \frac{\partial G K}{\partial x_{j}}\right)+G\left(S-\varepsilon+F_{k}\right)
\end{aligned}
$$

[ $\varepsilon$ の輸送方程式]

また，

$$
\begin{aligned}
& G \frac{\partial \varepsilon}{\partial t}+\frac{\partial G U_{j} \varepsilon}{\partial x_{j}}=\frac{\partial}{\partial x_{j}}\left(\frac{\nu_{t}}{\sigma_{E}} \frac{\partial G \varepsilon}{\partial x_{j}}\right) \\
& +G \frac{\varepsilon}{K}\left(C_{1 E} S-C_{2 E} \varepsilon+F_{E}\right) \cdots \cdots
\end{aligned}
$$

$$
\begin{aligned}
& S=-\frac{\overline{U_{i} U_{j}}}{G} \frac{\partial G U_{i}}{\partial x_{j}} \ldots \ldots \ldots \ldots \ldots \ldots \ldots \ldots \ldots \ldots(5) \\
& \overline{U_{i} U_{j}}=-\frac{\nu_{t}}{G}\left(\frac{\partial G U_{i}}{\partial x_{j}}+\frac{\partial G U_{j}}{\partial x_{i}}\right)+\frac{2}{3} K \delta_{i j} \cdots \cdots(6) \\
& F_{x_{i}}=C_{f_{t}} a_{x_{i}} U_{i}\left|U_{i}\right| / 2 \\
& F_{k}=U_{i} F_{x_{i}} \\
& F_{E}=C_{\rho E} K^{3 / 2} / L \\
& C_{D}=0.09, \quad \sigma_{\kappa}=1.0, \quad \sigma_{E}=1.3 \text {, } \\
& C_{1 E}=1.44, \quad C_{2 E}=1.92
\end{aligned}
$$

ここで, $i, j, k=1,2,3$, 添字の繰り返し炇総和を とり， $\delta_{i j}$ はクロネッカーのデルタである。また，各係 数およびモデル定数の値は，ラフネスが有る所で各粗度 形状に対応する值を与え，ラフネスが無い所では， $F_{x i}$ $=F_{k}=F_{E}=0.0$ とした。ラフネスが無いとき, 乱流モ デルは標準型 $k^{-} \varepsilon$ モデルと一致する。変数および係数 の意味は以下のとおりである。

$a_{x i}$ :

単位空間あたりの粗度要素の $x_{i}$ 軸方向見付け面績 単位空間あたりの流体体積

$C_{f_{t}}:$ 粗度要素の $x_{i}$ 軸方向抵抗係数

$C_{\rho E}:$ モデル係数

$G:$ 単位空間あたりの流体体積

$K$ : 単位流体体積あたりの時間平均乱流エネルギー

$L:$ 粗度要素の $x_{i}$ 軸方向見付け幅

$P$ : 単位流体体積あたりの時間平均圧力

$t:$ 時間

$U_{l}$ : 単位流体体積あたりの $x_{i}$ 溂方向時間平均風速

$: U_{1}=U, \quad U_{2}=V, \quad U_{3}=W$

$x_{i}: x_{1}=x, \quad x_{2}=y, \quad x_{3}=z$

$\varepsilon$ : 単位流体体積あたりの時間平均エネルギー消散 率

$\nu_{t}:$ 渦動粘性係数 $\left(=C_{D} K^{2} / \varepsilon\right)$

$\rho:$ 空気密度 

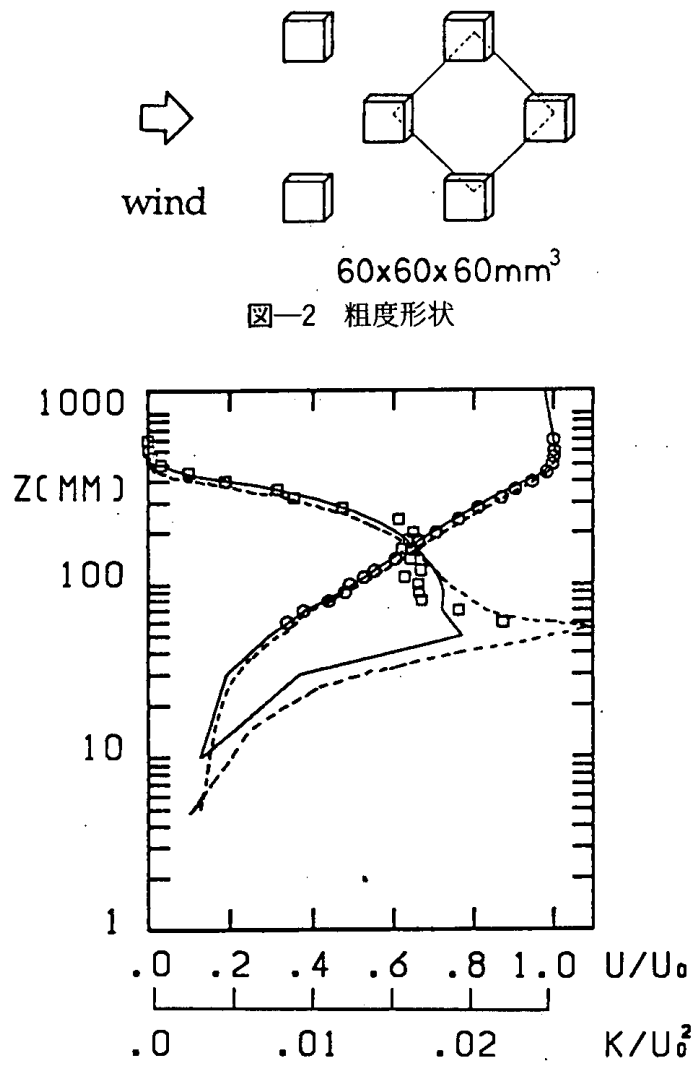

図一3 3 次元計算結果と 2 次元および実験結果との比較, $x=$ $7.44(\mathrm{~m}), y=0.0(\mathrm{~m}), \quad G=0.875, C_{f_{1}}=1.90, a_{x}=$ $2.31(1 / \mathrm{m}), C_{f_{2}}=0.0, a_{z}=0.0(1 / \mathrm{m}), C_{D E}=2.5$ : 実験值, $\bigcirc, U ; \square, K$; 計算結果, 一, 3 次元 ; $\cdots, 2$ 次元, $U_{0}$, 基準風速

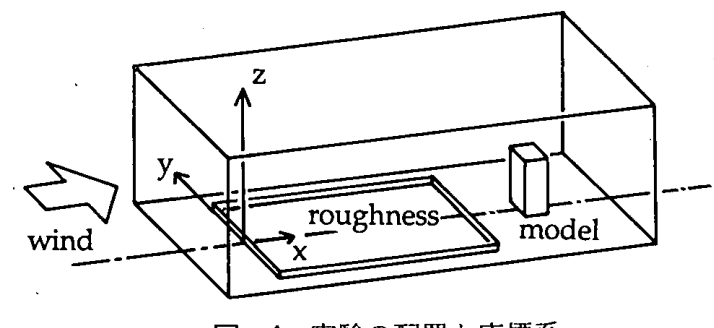

図一4 実験の配置と座標系

\section{3 領域分割および境界条件}

計算は 2.1 に述べたように各領域ごとに行った。変数 配置は staggered mesh 系を用い,メッシュ分割は計算 領域の形状と, 要求される解析精度に応じて選んだ。領 域 I の流入境界には一様流 : $U=1.0, V=W=0.0, K$ $=1.0 \times 10^{-5}, \varepsilon=6.21 \times 10^{-7}$, を与え, 固体壁面に対し ては壁面境界条件的踏をを用い，滑面上に乱流境界層を発 達させた。流出境界では自由流出条件的的2) 用いた。領 域 II の流入境界には領域 I の, 領域 IIIには領域 II の計算 結果をそれぞれ用いた。領域 II，而の固体壁面に対して は壁面境界条件を,流出境界には自由流出条件を用いた。 領域Iにおいてラフネスの体積変化がある部分では，ラ フネスの体積変化の割合に応じて粗度要素表面に壁面境 界条件を適用した付象了。なお，解析領域，メッシュ分割， 境界条件等の詳しい検討は文献》を参照されたい。
2.4 計算方法およびラフネスパラメータ

計算には ABMAC 法, 時間に関して Euler スキーム, 空間に関して 2 次精度の中心差分（ただし，K, $\varepsilon$ に関 して移流項は風上差分）を用いた。

乱流モデル中に現れる抵抗係数 $C_{f i}$ およびモデル係数 $C_{P E}$ (以後両者をまとめてラフネスパラメー夕と呼ぶ） の值は，2 次元の計算結果から得られた值を用いた。2 次元計算と 3 次元計算の差をチェックするために, 図一 2 に示すような粗度形状に対して 3 次元計算を行い， 2 次元計算および風洞実験結果 ${ }^{4}$ との比較を行った。ラj ネスの風洞内配置，メッシュ分割，境界条件を全く同じ にした場合の計算結果を図一3に実験結果と共に示す。 計算および実験結果は 2 次元との対応を考え，風洞中心 軸上 $(y=0 \mathrm{~m})$ の値を比較した。座標系は図一4に示す ようにラフネスの風上端中央を原点に取ってある。図一 3 より, 3 次元の計算結果は実験結果を良く再見し， 2 次元の計算結果とも良く対応している。また，ここで示 したラフネス以外の粗度形状に対しても，2 次元計算と 3 次元計算の比較を行ったが,大きな差は生じなかった。 これより，2 次元計算の結果から得られたラフネスパラ メータの值を用いて 3 次元計算ができると考え, 以下の 計算に用いた。

\section{3. 計算結果と考察}

3.1 乱流境界層のシミュレーション

領域 II， III の 3 次元計算例を図一 5,6 に示す。ラフ ネスは図一2 2同じものを用い，領域 IIIには実験対象と なる模型が無い場合を想定している。図一5，6より風 洞内の乱流境界層の発達の様子がわかる。ラフネスの風 上端では風速の鉛直上方成分が増加し, また, 多くの乱 流エネルギーが生じている。乱流エネルギーは境界層の 発達とともに上方に拡散し, 上空の乱れが増加している。 ラフネスの風下側では床面の抗力が小さくなるので，風 速の鉛直下方成分がラフフネス風下端で増加し，また， 床面付近の $x$ 軸方向成分が下流に行くに従って増加す る。ラフネスは風洞側壁まで敷き詰められていないので, 床面両隅のラフネスが無い部分では風速が中心部よりも 大きくなっている。

このように，粗度形状とそれに対応するラフネスパラ メータの值がわかれば風洞内における乱流境界層の発達 の様子が計算できる。したがって，実際の風洞実験に先 だって，希望する気流性状を持った乱流境界層を作り出 すために必要な粗度形状と風洞内におけるラフネスの配 置方法を予测することができる。また，種々の気流性状 を持った乱流境界層を計算で作りだし，他の計算の流入 気流条件として用いることができる。次節でその一例を 示す。 

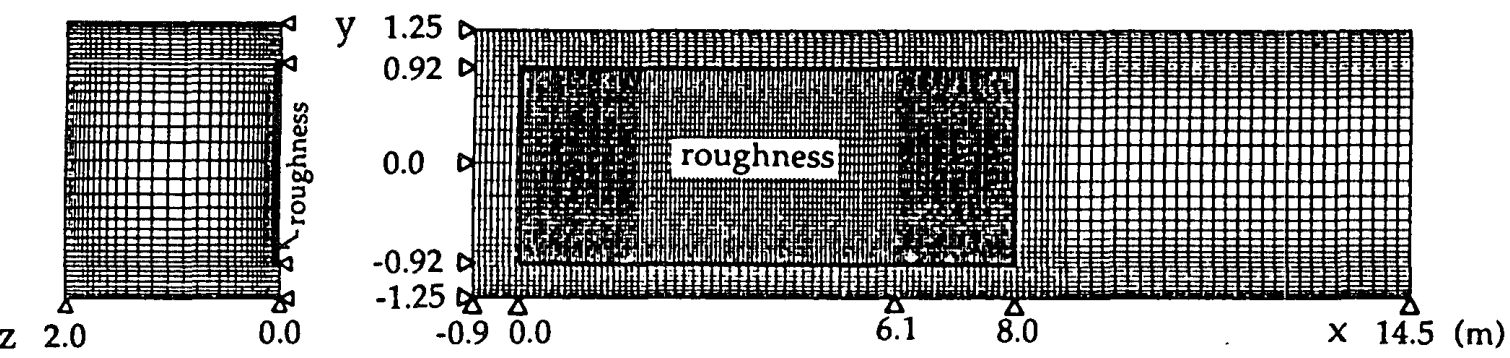

mesh discretization
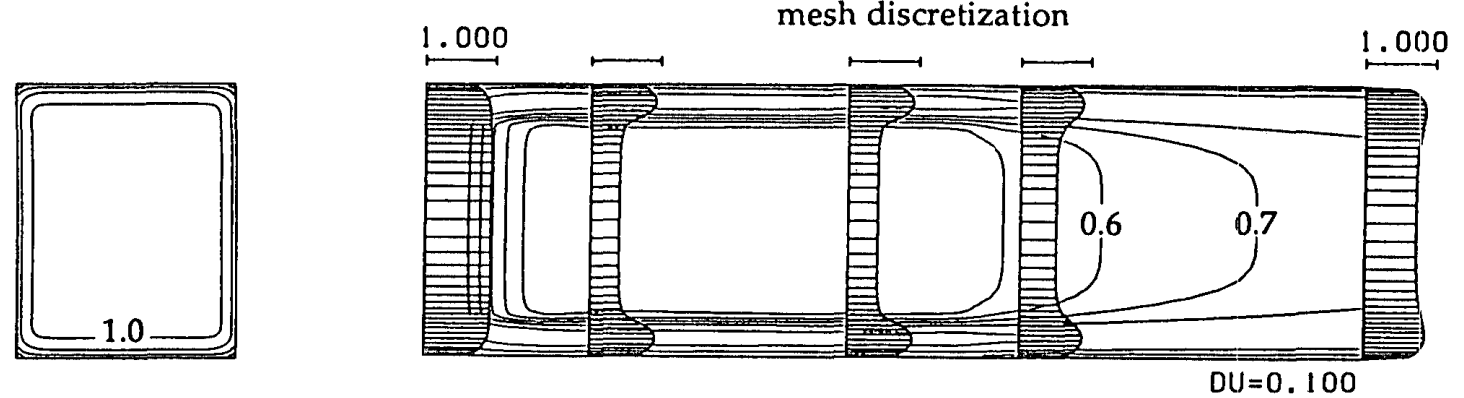

streamwise velocity : $U$
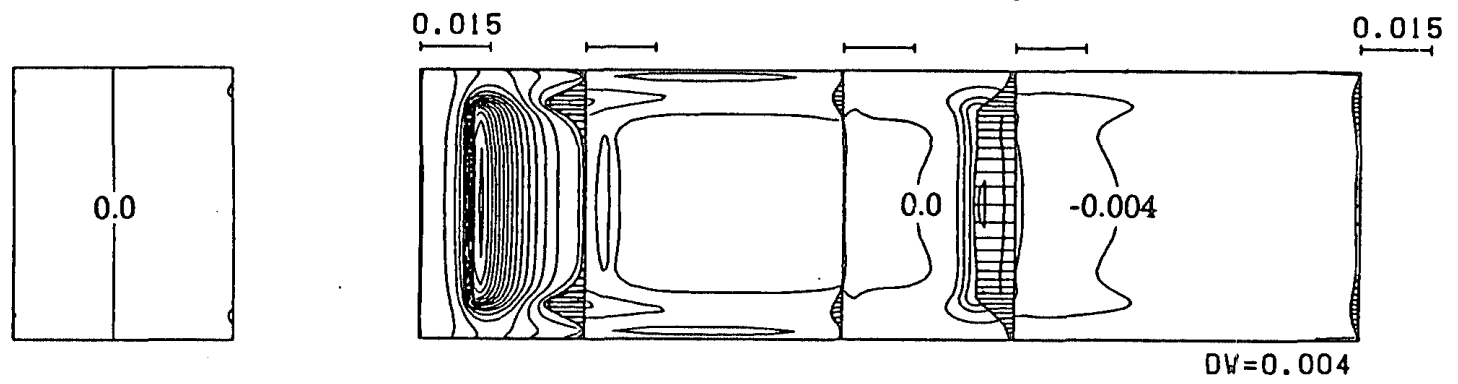

vertical velocity : $W$

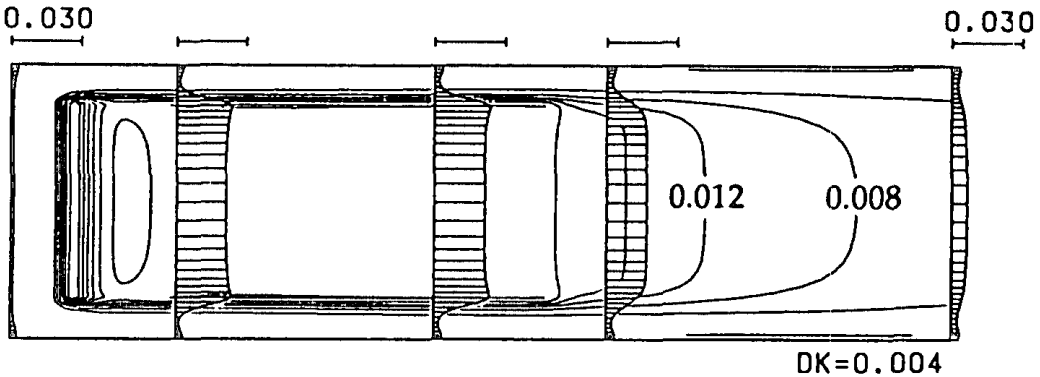

kinetic energy : $\mathrm{K}$

$z-y$ 平面, $x=-0.9 \mathrm{~m}$

$x-y$ 平面, $z=-0.35 \mathrm{~m}$

図一5 3 次元計算結果の分布図およびプロファイル

\subsection{3 次元数値風洞実験}

領域 IIIに直方体を設置する場合を想定し，3 次元定常 流れ場の数值実験を行う。領域四におけるメッシュ分割 および直方体の位置を図一7に示す。種々のラフネスパ ラメータを用い, また, ラフネスの位置を変えた計算結 果から, 種々の気流性状を持った乱流境界層を数值風洞 内に発達させ,その結果を流入条件として用いた。一例 として, 図一8に示すように, 厚さが同じで, 気流性状 の異なる 3 つの接近流 flow A，B，C を用い，風速勾配 および乱れの分布形状の違いによる変化を調べた。対応 する直方体の風上側壁面平均風圧分布形状を図一9に示 す。図中の風圧係数 $C_{p}$ の值は, 図一7に示すように, 領域而の流入境界における中心軸上の直方体高さにおけ
る基準速度圧 $q=\rho U_{0}^{2} / 2$ および静压 $p_{0}$ によっで式 (11) のように求めた。

$$
C_{p}=\frac{p-p_{0}}{q}
$$

ここで, $p$ は直方体壁面における静珐である。図一 9 上 り, 平均風圧分布形状は接近流によって変化し, flow $\mathrm{A} ， \mathrm{~B} ， \mathrm{C}$ と風速勾配が急になるに従って，圧力の高い 領域が上方に移動し，その最高値も大きくなるのがわか る。この結果は他の実験結果 ${ }^{10)}$ と定性的に一致する。

ここで, 流入条件として用いた 3 つの接近流 flow A, B，Cは，それぞれ，滑面，千鳥状配列立方体粗度ブロッ クを用いた粗面 $(G=0.025)$ ，同粗面（G=0.25）上に 発達させたもので, ラフネスの吹送距離はflow B で 


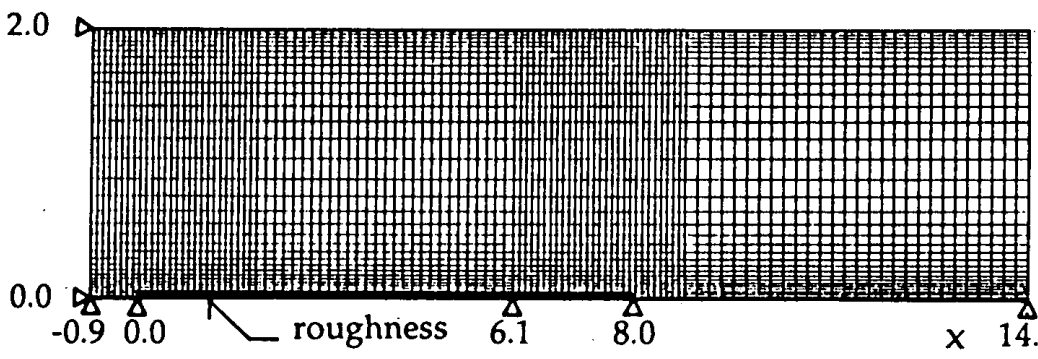

mesh discretization

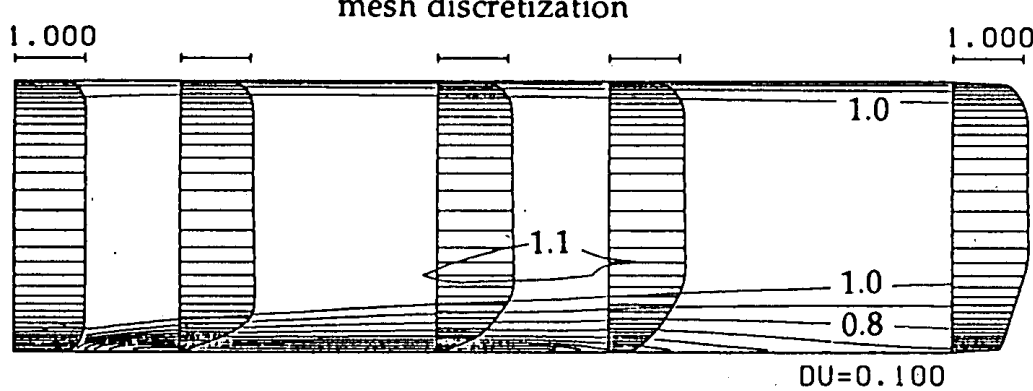

streamwise velocity : $U$

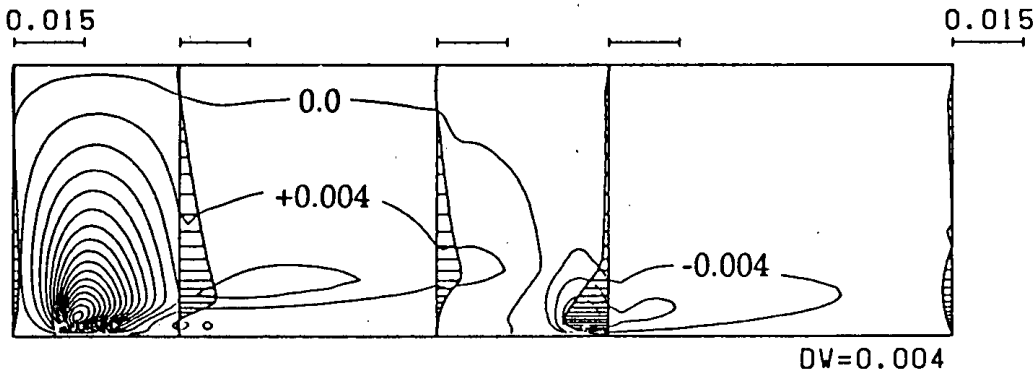

$D V=0.004$

vertical velocity : $W$

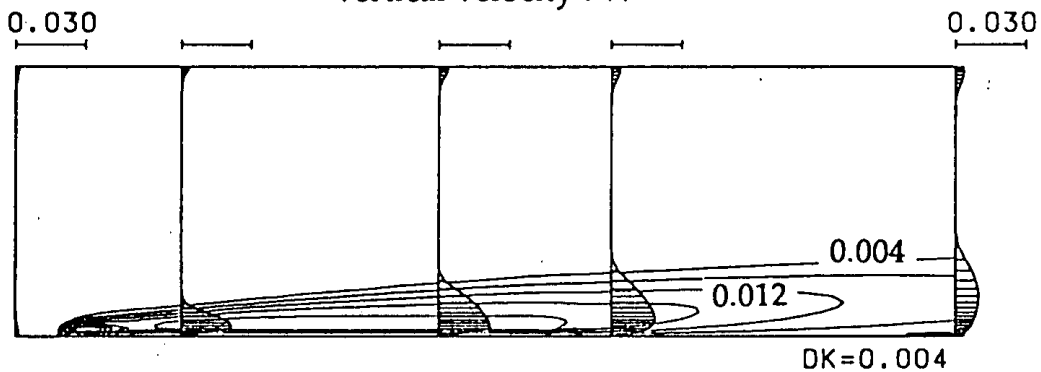

kinetic energy : $\mathrm{K}$

$x-z$ 平面, $y=0.0 \mathrm{~m}$

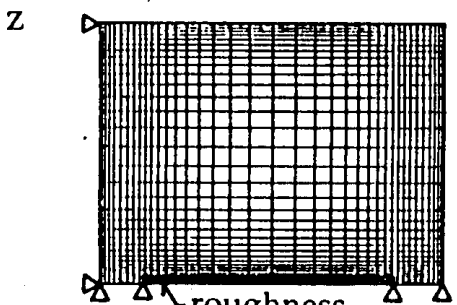

1.250 .92
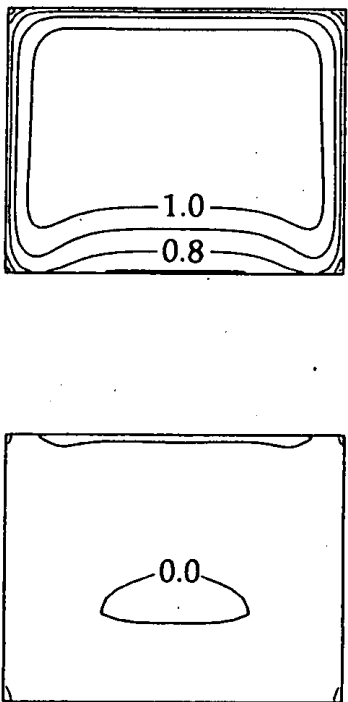

図一 3 次元計算結果の分布図およびプロファイル

$18.2 \mathrm{~m}, \mathrm{C}$ で $7 \mathrm{~m}$ である。A゙では境界層の厚さがすぐ には厚くならないので，周期境界条件を使った。このよ うに，吹送距離が長くて夷際の風洞ではなかなか作り出 すことができないような気流性状も計算では作り出すこ とができ，数值風洞ではそのような条件のもとで奏験が できる。また，高次の乱流モデルを用いれば，より詳し い3 次元流れ場の解析に応用できる。ただし，ここで示 した計算手法は定常流れ場しか計算できないので, LES や直接法など非定常流れ場の解析に用いるために は, 何らかの統計的な手法を用いて, 時系列デー夕に変 換する必要がある。

\section{4. まとめ}

本報では，粗度形状および体積変化を考慮した $k-\varepsilon 2$ 方程式乱流モデルを用いた高レイノルズ数定常流れ場の 解析手法を 3 次元計算に挔張し，風洞内に発達する乱流 境界層の数值シミュレーションに適用した。3 次元計算 と 2 次元および実験結果との比較により，本報で示した 計算手法が有効であることを確かめ，直方体を用いた簡 単な数值風洞実験によって，数值風洞への忘用を検討し た。得られた結果を以下にまとめる。

1) 粗度形状とそれに対応するラフネスパラメータの值 がわかれば，ラフネス上の乱流境界層の発達の様子が計 算できる。

2)本手法を用いれば，実際の乱流境界層を用いた風洞 

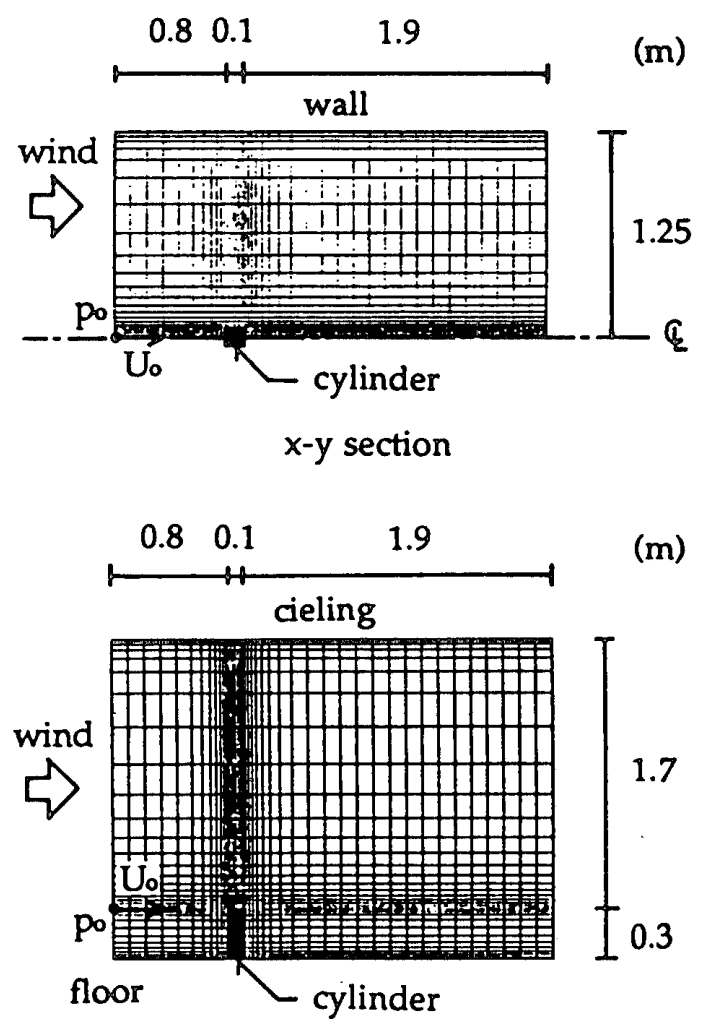

$\mathrm{x}-\mathrm{z}$ section

図一7 領域におる直方体の位置およびメッシュ分割

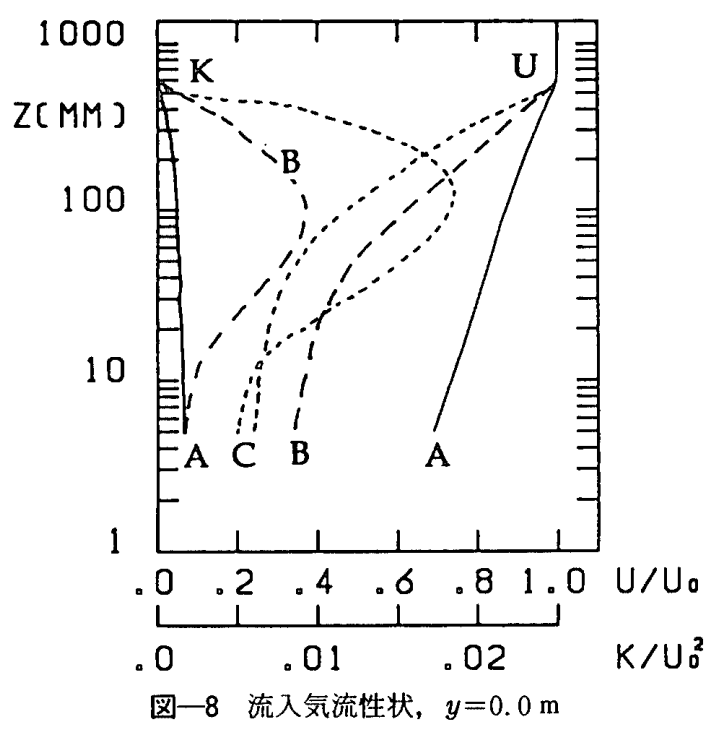

実験に先だって，実験結果の予測を行うことができ，補 完的な道具としての利用が大いに期待できる。

3）奏際の実験が困難な数值実験を行う場合に，流入気 流条件として用いる種々の気流性状を計算で発生させる ことができる。

ここで, 建物等, 物体周りの数值風洞実験に関しては, 高次の乱流モデルを用いることによって，より詳しい 3 次元流れ場の解析が期待できる。ただし，本手法を用い て作り出すことのできる種々の気流性状は，定常流れ場 の值であるため，その結果をLES や直接法など非定常 流れ場の解析に応用するためには，何らかの統計的な手

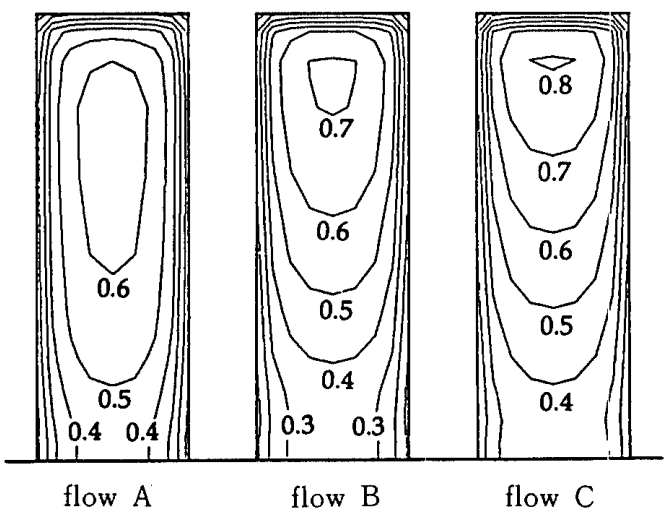

图一9 接近流の気流性状の違いによる風上側壁面に才ける平均 風王分布の変化

法を用いて, 時系列データに変換する必要があり, 今後 の課題である。

謝 辞

数値計算を行うにあたり, 京都大学助手平岡久司氏か ら有用な意見を数多くいただいた。ここに記して謝意を 表する。なお，本研究の一部は文部省科学研究費の援助 を受けて行われたものである。

\section{参考文献}

1）平岡久司，丸山敬，中村泰人・桂 順治：植物群落内 および都市キャノピー内の乱流モデルに関する研究（そ の 1) 乱流モデルの作成, 日本建筑学会計画系論文報告集, 第 406 号, pp. 1 9, 1989. 12.

2）平岡久司, 丸山 敬, 中村泰人 - 桂 順治 : 植物群落内 および都市キャノピー内の乱流モデルに関する研究（そ の2）実験データとの比較によるモデルの検証，日本建 築学会計画系論文報告集, 第 416 号, pp. 1 8, 1990. 10.

3）丸山 敬：粗面上に発達する乱流境界層の $k$-ミモデルに よるシミュレーション (その 3 : 境界条件による変化), 第 5 回生研 NST シンボジウム講演諭文集, pp. 9 12, 1990.2.

4）丸山敬：粗度要素の抵抗および体積変化を考慮した $k-\varepsilon$ モデルによる乱流境界層の数值計算, 日本建築学会 構造系論文報告集，第 404 号, pp. 75 81，1989. 10.

5）丸山 敬：粗面上に発達する乱流境界層の数値シミュ レーション（その $2:$ 市街地のように粗度形状が複雑な 場合), 日本風工学会誌, Vol. 47, pp. 81 82, 1991. 4 .

6）丸山 敬：粗面上に発達する乱流境界層の数值シミュ レーション, 第 11 回風工学シンポジウム, pp. 203 208, 1990. 12.

7) 例えば, Paterson, D.A and C. J. Apelt : Computation of wind flows over three-dimentional buildings, Journal of Wind Engineering and Industrial Aerodynamics, Vol. 24, pp. 193 213, 1986.

8) 例えば, Murakami, Shuzo and A. Mochida : Threedimensional numerical simulation of air flow around a cubic model by means of large eddy simulation, Jour. nal of Wind Engineering and Industrial Aerodynamics, Vol. 25, pp. 291 305, 1987.

9) 例えば, Tamura, Tetsuro and K. Kuwahara, Numeric. 
al study of aerodynamic behavior of a square cylinder, Jounal of Wind Engineering and Industrial Aerodynamics, Vol.33, pp. 161 170, 1990.

10）亀井勇, 吉田正昭, 本郷 剛：風の垂值分布を考虑せ る角柱の風速分布に関する研究, 日本建築学会大会学術 講演梗概集, pp. 275 276, 1970.9 .

\section{付 録}

1）壁面境界条件：ここでは，壁面境界上で法線方向の風速 成分が零，法線方向の勾配 $\partial / \partial n$ について，接線方向の 風速成分に関してはべき法則（べき指数 1/7) が成り立 つとし，他の変数に関しては零となるように仮想セルに おける各変数の值を与える。 $\varepsilon$ に関しては壁面第 1 七ル で対数法則が成り立つとし，壁面からの距離 $\Delta z$ と $K$ を 用いて $\varepsilon=K^{3 / 2} C_{D}^{3 / 4} /(0.4 \Delta z)$ とする。

2) 自由流出条件：ここでは, 法線方向の勾配 $\partial / \partial x$ が零上 なるように仮想セルにおける $U, V, W, P, k, \varepsilon$ の值を 与える。

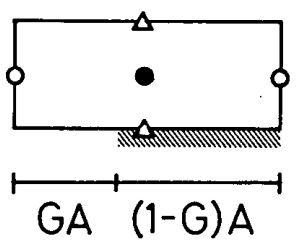

図一a ラフネス上面に接するセル, $\bigcirc, U ; \Delta, W ; \boldsymbol{O}, V, P$, $K, \varepsilon$

3） ラフネスの体積変化がある部分においてラフネス上面に 接するセルを図 $\mathrm{a}$ に示す。このセルの下面面積を $\mathrm{A}$ とす ると, 下面のうち GA が下層の流体部分と，(1-G) A が ラフネス上面に接している。そこで，このセル内での差 分計算に際して，下面のうち 1-G の割合で固体壁面が占 めるとし，その分については壁面境界条件を用いた。

（1991 年10月 9 日原稿受理，1992 年 4 月 15 日採用炔定） 